\title{
WestVirginiaUniversity
}

THE RESEARCH REPOSITORY @ WVU

Graduate Theses, Dissertations, and Problem Reports

2018

\section{Investigation into composting efforts at WVU: a case study.}

Marina Alexis Berry

Follow this and additional works at: https://researchrepository.wvu.edu/etd

\section{Recommended Citation}

Berry, Marina Alexis, "Investigation into composting efforts at WVU: a case study." (2018). Graduate Theses, Dissertations, and Problem Reports. 3991.

https://researchrepository.wvu.edu/etd/3991

This Problem/Project Report is protected by copyright and/or related rights. It has been brought to you by the The Research Repository @WVU with permission from the rights-holder(s). You are free to use this Problem/Project Report in any way that is permitted by the copyright and related rights legislation that applies to your use. For other uses you must obtain permission from the rights-holder(s) directly, unless additional rights are indicated by a Creative Commons license in the record and/ or on the work itself. This Problem/Project Report has been accepted for inclusion in WVU Graduate Theses, Dissertations, and Problem Reports collection by an authorized administrator of The Research Repository @ WVU. For more information, please contact researchrepository@mail.wvu.edu. 
Investigation into Composting Efforts at WVU; a Case Study

Marina A. Berry

Problem Report submitted to the

Davis College of Agriculture, Natural Resources and Design at West Virginia University

in partial fulfillment of the requirements

for the degree of

Master of Science

in

Nutritional and Food Science

Robert Taylor, $\mathrm{PhD}$, Chair

Megan Govindan MPH, MS, RDN, LDN

Sven Verlinden, $\mathrm{PhD}$

Department of Human Nutrition and Foods

Morgantown, West Virginia

2018 


\section{ABSTRACT \\ Investigation into Composting Efforts at WVU; a Case Study \\ Marina A. Berry}

Institutional composting systems have been adopted by many land grant universities to help better manage their waste and protect the environment. West Virginia University (WVU) has yet to begin formally managing their animal manure and waste at the university farms. This investigation will look into what has been done at other land grant universities to see which methods could be applied at WVU. This could have environmental, economic, and social benefits and also serve as a living learning classroom. University composting systems have often started small and grown to accommodate campus food waste, which could also be a possibility for West Virginia University. 


\section{TABLE OF CONTENTS}

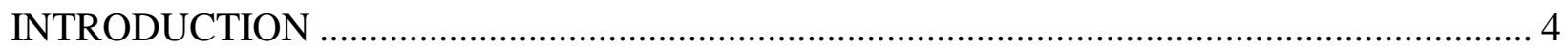

Problem Statement ..................................................................................................... 4

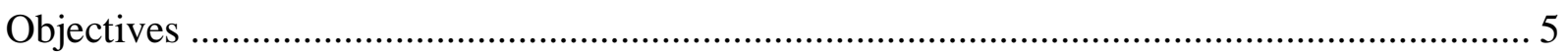

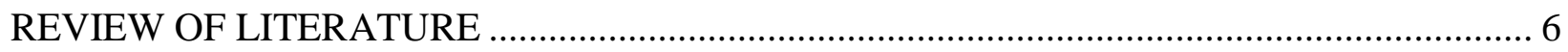

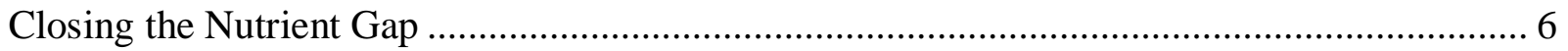

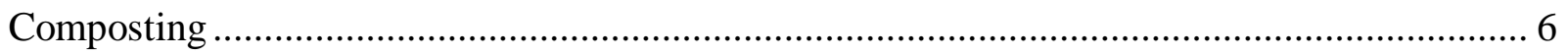

Role of Land Grant Universities ................................................................................ 12

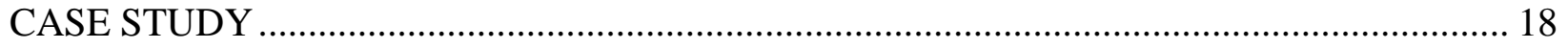

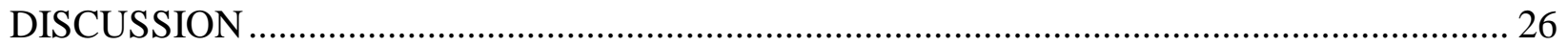

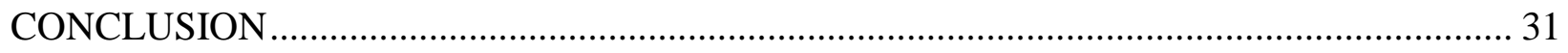

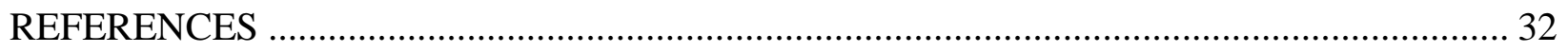

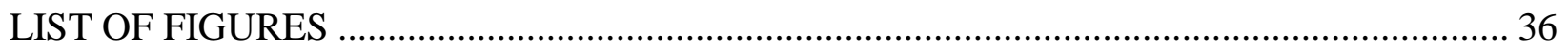

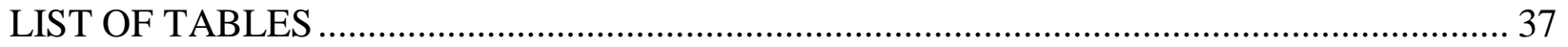

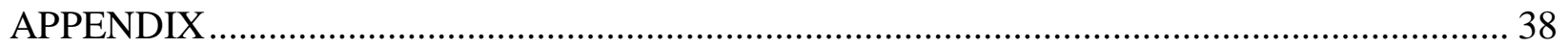

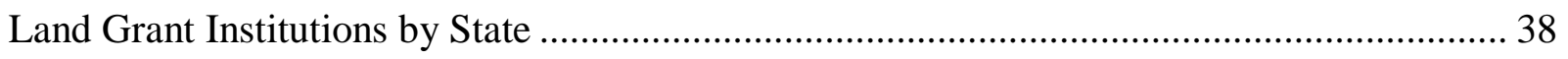




\section{INTRODUCTION}

Many land grant universities (LGUs) across the country have developed zero waste plans which include not only recycling, but also composting of farm waste and food waste. These alternatives allow waste to be diverted from landfills and reutilized or reintroduced into our food system. A solid waste diversion rate of more than 50 percent cannot be achieved without including organics into the recycling efforts (Themelis \& Arsova, 2015). Composting also has many agricultural, environmental, economic and social benefits. However, this type of large scale institutional composting is not possible without a system to properly develop the compost. If compost is not developed properly it can cause more harm than good, because compost requires time to breakdown and transform. This is especially the case if it contains animal manure, as is the case at West Virginia University (WVU) currently.

The purpose of this study is to evaluate WVU's current composting efforts and address the feasibility of a new waste management system. Other land grant universities' composting systems will be compared to see which have been most successful, as well as to see which methods could be applied at WVU. Improving WVU's composting system will allow us to reap similar benefits that other LGU's have seen and create opportunities for teaching, research, and outreach. It would also teach both students and the community how to be better environmental stewards by being mindful of our waste. This area is a weak spot in our local food system and needs to be investigated and improved upon.

\section{Problem Statement}

Due to an informally managed compost system at the WVU Animal Sciences Farm, some raw manure and other waste is running off into the environment as well as being transferred to the WVU Organic Farm to treat soil in an inopportune form. 


\section{Objectives}

The objectives of this investigation are to:

- Identify composting efforts at other LGUs

- Evaluate current composting efforts at WVU

- Compare methods of composting to see which would best fit our needs

- Identify any barriers to changing the waste management system

Methods of institutional composting and model land grant universities utilizing these

methods need to be investigated, then suggestions will be made to improve the waste

management at WVU. 


\section{REVIEW OF LITERATURE}

\section{Closing the Nutrient Gap}

When food waste, yard scraps, and animal manure are not diverted back into our food system it creates a gap in what could otherwise be a continuous nutrient cycle. This is because each of these wastes contain nutrients that can be introduced back into soil to help grow new crops. Organic and inorganic matter cycle through this loop in various forms, including: soil, plants, animals, humans and their waste. The balance of these nutrients in the soil, such as Nitrogen and Phosphorus, is a delicate ratio necessary for plant growth. The wrong ratio will harm plant growth and when too much is added to soil it will runoff into the surrounding environment or contaminate groundwater. This runoff can be harmful to the environment and also means that these nutrients are not being directed back into the agricultural and food systems. Composting allows for these nutrients to be harnessed and applied back to the soil. However, the overapplication of compost could also lead to too much organic material accumulating in the soil.

\section{Composting}

The composting process converts organic waste materials into environmentally beneficial soil amendments, diverts wastes from landfills, and treats these wastes to control pathogens, whether human, animal, or plant (Crohn, 2011). The science of composting is complex and includes multiple overlapping process: physical, chemical, and biological. Bacteria are the powerhouse of a compost pile. They break down plant matter and release carbon dioxide and heat. The process also requires moisture and aeration to move the process along.

With the growing concern about the impact of agriculture on water quality and heightened interest in managing agricultural by-products economically, the use of composting by 
US farmers is increasing (Kashmanian \& Rynk, 1998). National composting statistics are hard capture due to the lack of policies requiring data collection from composting facilities (Themelis \& Arsova, 2015). Much of the smaller scale composting by US farmers is likely unreported due to it being for personal rather than municipal use. The reported the total number of permitted composting facilities in the US is 4,914 (Platt et al., 2014). The majority of these, $71 \%$, compost only yard trimmings (Themelis \& Arsova, 2015). Food waste is accepted for processing by 347 composting operations (Themelis \& Arsova, 2015). However, a growing number of composting operations are upgrading their permits and infrastructure to process food waste.

Composting allows for better disposal of solid manure from livestock operations and can also accommodate food waste along with it. This composting of the solid manure also allows for better control of manure that is applied to the land. When it is matured via composting it is safer for the environment and slowly releases its nutrients to the soil.

The use of compost has agricultural, environmental, economic, and social benefits. Some of the agricultural benefits of the application of compost include: improvement of the physical properties of soils, enhancement of the chemical properties of soils, and improvement of the biological properties of soils (Chen \& Wu, 2005). Incorporating composts into compacted soils improves root penetration and turf establishment in lawns, golf courses, and sports fields. The water-holding capacity of the soil is increased by water binding to the newly introduced organic matter, which means lower water requirement. Soil aeration is also improved, which allows oxygen to reach the roots more readily (Chen $\& \mathrm{Wu}, 2005$ ). Compost can build up the nutrient content of the soil, as it contains the major nutrients required by plants: $\mathrm{N}, \mathrm{P}, \mathrm{K}, \mathrm{Ca}, \mathrm{Mg}$, and $\mathrm{S}$. The benefits of composting will last for more than one growing season because the nutrients are 
slowly released (Chen $\& \mathrm{Wu}, 2005)$. Compost not only benefits the soil, but also the surrounding environment.

The environmental benefits of composting include pollution remediation and pollution prevention (Chen \& Wu, 2005). Compost absorbs odors and degrades volatile organic compounds. Compost also binds heavy metals and prevents them from migrating to water resources or being absorbed by plants (Chen \& Wu, 2005). Composting prevents methane production in landfills by diverting organics for composting use. Composting raw manure can minimize any potential environmental or nuisance problems. Raw manure is one of the primary culprits in the pollution of waterways (Chen \& Wu, 2005). Diverting this raw manure to composting allows it to be repurposed and put back into the soil.

The social and economic benefits of composting include bringing higher prices for organically grown crops and extending current landfill longevity. Compost helps keep plants healthy by controlling weeds, providing a slow release of nutrients, and preventing soil loss through erosion (Chen \& Wu, 2005). Raw manure often contains weed seeds which are killed by the heat of the compost pile. Healthier plants allow for higher prices which would benefit farmers. Landfills would also fill up at a slower rate if more food waste was diverted to composting. This would extend the lifetime of current landfills and put off the building of new landfills.

However, given all the benefits of compost there are also some downsides. The agricultural uses of compost remain low for several reasons. Firstly, compost tends to be heavy and bulky, making it hard to transport (Chen \& Wu, 2005). The nutrient value of compost is low compared with that of chemical fertilizers, which may mean a lower nutrient release than farmers would like (Chen \& Wu, 2005). The nutrient composition of compost is also highly variable in 
comparison to chemical fertilizers. Lastly, long-term and/or heavy application of composts to agricultural soils has been found to result in salt, nutrient, or heavy metal accumulation and may adversely affect plant growth, soil organisms, water quality, and animal and human health (Chen $\& \mathrm{Wu}, 2005)$. In addition, if compost is not properly managed these drawbacks can become a larger issue because the Nitrogen to Carbon ratio would not be appropriate for soil application.

If compost is not managed properly it can cause additional problems. When piles are improperly constructed, including piles not turned regularly or piles with uneven sections, this can provide refuge and breeding areas for some insects (Mason, 2016). This is because if some areas of the pile are thinner than others, especially at the edge of the pile, the temperature would be lower and habitable for insects. The attraction of insects could harm nearby plants.

Another sign that something is wrong with a compost pile is odor because ordinarily composting should not smell. Any rotten or ammonia smells indicate that something is out of balance with the compost (Composting Problems, 2010). Rotten smells are an indication that the pile has gone anaerobic and needs to be turned to have oxygen introduced. If the pile keeps reverting to an anaerobic mode, it is time to explore different ingredient ratios or composting styles (Composting Problems, 2010). An ammonia-like smell can indicate that too many highNitrogen products have been added to the pile. The Nitrogen to Carbon ratio is a delicate balance for composting to work properly. The proper ratio is 25-30 parts Carbon to 1 part Nitrogen, or 25-30:1 (Composting Problems, 2010). Green products (grass clippings, corn meal, etc.) are the main contributor of Nitrogen, whereas brown products (straw, sawdust, etc.) are the main contributor of Carbon to the pile (Composting Problems, 2010).

Another common issue is that the compost does not heat up, which is an important part of its proper functioning. It is important to realize that only freshly built or freshly turned piles will 
get hot and stagnant piles will not (Composting Problems, 2010). Even if the carbon-nitrogen and moisture balance in the new material is perfect there may not be enough of it, depending on the size of the original heap, to support the mass of microbes needed to create a hot pile. In this case, the pile either needs to be turned or new material needs to be added. For the compost to be developed properly it must be cared for by someone who knows how to manage this balance.

They key to good compost is that its mature. Immature compost does more harm than good because it has not been given time to properly transform and achieve a proper $\mathrm{C}: \mathrm{N}$ ratio (CalRecycle, 2013). The amount of time needed to produce compost depends on several factors, including the size of the compost pile, the types of materials, the surface area of the materials, and the number of times the pile is turned. Large piles are limited by a person's ability to turn the compost. By turning more frequently (1-2 times per week), you will produce compost more quickly. Waiting at least two weeks allows the center of the pile to heat up and promotes maximum bacterial activity. The average composter turns the pile every 4-5 weeks (University of Illinois Extension, 2017). With frequent turning, compost can be ready in about 3 months, depending on the time of year. In winter, the activity of the bacteria slows, and it is recommended that the operator stop turning the pile to keep heat from escaping from the pile's center. In summer, warm temperatures encourage bacterial activity and the composting process is quicker (University of Illinois Extension, 2017).

There are various forms of composting structures that can be effective on a larger, institutional scale. The first of these forms is windrows, which are long rows approximately 4 to 8 feet high and 14-16 feet wide (US EPA, 2015). This style allows for large volumes to be composted at a relatively low cost. Windrow composting often requires large tracts of land, sturdy equipment, a continual supply of labor to maintain and operate the facility, and patience to 
experiment with various materials mixtures and turning frequencies (US EPA, 2015). The main piece of equipment required is a turner, which is either driven or pulled by a tractor over the windrows.

Aerated static pile composting produces compost relatively quickly (within three to six months). Organic waste is mixed in a large pile. To aerate the pile, layers of loosely piled bulking agents, such as wood chips or shredded newspaper, are added so that air can pass from the bottom to the top of the pile. The piles also can be placed over a network of pipes that can move air into or out of the pile (US EPA, 2015). This method works well for larger quantities, however does not work as well for composting animal byproducts.

In-vessel composting can process large amounts of waste without taking up as much space as the windrow method and it can accommodate virtually any type of organic waste. This method involves placing materials into a drum, silo, concrete-lined trench, or similar equipment. This allows good control of the environmental conditions such as temperature, moisture, and airflow (US EPA, 2015). The smaller in-vessel composting methods often have a crank mechanism for turning its contents.

One smaller scale composting method of growing interest is vermicomposting. Red worms in bins feed on food scraps, yard trimmings, and other organic matter to create compost. The worms break down this material into high quality compost called castings (US EPA, 2015). One pound of mature worms (approximately 800-1,000 worms) can eat up to half a pound of organic material per day (US EPA, 2015). The bins can be sized to match the volume of food scraps that will be turned into castings.

Composting can be produced in both small scale or large scale settings. Compost provides beneficial nutrients to the soil and must be applied it moderation to achieve best results. 
If properly managed compost provides a viable product for agricultural use while diverting waste from landfills. Composting also helps protect our environment and groundwater supply by limiting runoff of animal manure.

\section{Role of Land Grant Universities}

Many college campuses, especially LGUs, have been developing their own institutional composting programs which creates an excellent opportunity to educate the campus community about how to compost and its benefits. Composting also benefits these school by providing a cost-effective way to manage animal manure as well as an alternative to sending food waste to the land fill. The common reason that LGUs have developed composting programs was to better manage livestock manure.

A land grant institution is a college or university that has been designated by its state legislature or Congress to receive the benefits of the Morrill Acts of 1862 and 1890 (APLU, 2012). The original mission of these institutions, as set in the first Morrill Act, was to teach agricultural, military tactics, and mechanics as well as classical studies so that members of the working class could obtain a practical education. There was a growing demand for agricultural and technical education in the US at this time. Grants in the form of federal lands were provided to each state so they could establish a public institution to fulfill the Morrill Acts mission. Each of the states has their own land grant institution and some have two due to the second Morrill Act (APLU, 2012).

The three pillars of land grant institutions are teaching, research, and outreach (APLU, 2012). This is why land grant schools are not just focused on educating their students, but also having an impact on their community. For example, many land grant schools have county extension offices whose sole job is to provide programming and education to specific counties. 
Today, America's land grant universities continue to fulfill their original mission, including accessibility and service to people. Many have also become top ranked public research universities, the scope of study at these universities has grown far wider than their original focus.

However, at land grant universities today agriculture is still a major emphasis even with their broadening mission and wide variety of areas of study. This usually includes having campus farms for teaching and research. Many of these campus farms across the country feature composting systems, which serve a functional purpose for the university as well as act as a teaching tool. Below is a table that summarizes what other Land Grant Universities' methods of institutional composting are.

Table 1: Summary of Data Collected on Composting Methods at Other LGUs

\begin{tabular}{|l|l|l|}
\hline Land Grant University & Method of Composting & \multicolumn{1}{|c|}{ Unique Factors } \\
\hline University of Arizona & Windrows & $\begin{array}{l}\text { Run by a student organization, "Compost } \\
\text { Cats", who water, turn, and nurture the piles } \\
\text { until soil testing (UA Compost Cats, 2017). }\end{array}$ \\
\hline University of Arkansas & $\begin{array}{l}\text { Earth Tubs } \rightarrow \\
\text { Windrows }\end{array}$ & $\begin{array}{l}\text { Student run, food waste collected from } \\
\text { dining halls and weighed before composting } \\
\text { (Teague, 2011). }\end{array}$ \\
\hline $\begin{array}{l}\text { Colorado State } \\
\text { University }\end{array}$ & Windrows & $\begin{array}{l}\text { With the new windrows, CSU will repurpose } \\
\text { nearly 5,000 pounds of food waste from } \\
\text { residence hall dining centers every week } \\
\text { (Guiden, 2017). }\end{array}$ \\
\hline $\begin{array}{l}\text { University of } \\
\text { Connecticut }\end{array}$ & Windrows & $\begin{array}{l}\text { The Agricultural Composting Facility has } \\
\text { been composting about 800 tons of } \\
\text { agricultural waste per year (Composting at } \\
\text { UConn, 2017). }\end{array}$ \\
\hline University of Delaware & $\begin{array}{l}\text { Vermicomposting } \\
\text { proposal }\end{array}$ & $\begin{array}{l}\text { Indoors and managed by agricultural } \\
\text { students (Adler et al., 2009). }\end{array}$ \\
\hline University of Florida & Composting Tumblers & $\begin{array}{l}\text { Run by the Student Compost Cooperative, } \\
\text { which allows students to compost their own } \\
\text { food waste (Wilkie, 2017). }\end{array}$ \\
\hline
\end{tabular}




\begin{tabular}{|c|c|c|}
\hline University of Georgia & $\begin{array}{l}\text { Bioconversion } \\
\text { Laboratory }\end{array}$ & $\begin{array}{l}\text { The Campus Composting Project, which is } \\
\text { part of Zero Waste UGA, has composting } \\
\text { bins in all major campus buildings } \\
\text { (collecting 200-300 lb a week) which is then } \\
\text { brought to an off-campus composting facility } \\
\text { (Martin, 2017). }\end{array}$ \\
\hline University of Illinois & Vermicomposting & $\begin{array}{l}\text { The Sustainable Student Farm has a self- } \\
\text { contained vermicomposting facility that } \\
\text { collects food waste from dining halls (Grant, } \\
\text { 2015). }\end{array}$ \\
\hline Iowa State University & $\begin{array}{l}\text { Windrows (in hoop } \\
\text { barns) }\end{array}$ & $\begin{array}{l}\text { The composting operation was built in } \\
\text { conjunction with the ISU Dairy Farm, the } \\
\text { majority of the input comes from dairy } \\
\text { waste, but the remaining comes from campus } \\
\text { food and yard waste (Zahren, 2017). }\end{array}$ \\
\hline University of Maine & $\begin{array}{l}\text { Enclosed, Automated } \\
\text { Composting Unit }\end{array}$ & $\begin{array}{l}\text { The effort involves the purchase of a } 10 \text {-foot } \\
\text { by } 40 \text {-foot enclosed, automated composting } \\
\text { unit called the EarthFlow } 40 \text {, which can } \\
\text { convert more than } 1 \text { ton of organic waste per } \\
\text { day (UMaine, 2013). }\end{array}$ \\
\hline $\begin{array}{l}\text { Michigan State } \\
\text { University }\end{array}$ & $\begin{array}{l}\text { Vermicomposting \& } \\
\text { Anaerobic Digester }\end{array}$ & $\begin{array}{l}\text { The facility takes in } 12,000 \text { cubic yards } \\
\text { ( } 7,700 \text { tons) of solid manure or } 80 \% \text { of the } \\
\text { total produced on campus each year at a } \\
\text { second facility campus food waste is } \\
\text { combined with animal waste in an anaerobic } \\
\text { digester (Compost Research Site, 2012). }\end{array}$ \\
\hline University of Missouri & Compost Stalls & $\begin{array}{l}\text { The facility at the farm is } 2,400 \mathrm{sq} \mathrm{ft} \text { divided } \\
\text { into four stalls with } 5 \text {-foot cement walls. At } \\
\text { the current stage, the building does not have } \\
\text { a roof. Fist-sized holes in the back wall allow } \\
\text { for the tubes to aerate the piles (Zhang, } \\
\text { 2011). }\end{array}$ \\
\hline University of Nebraska & Vermicomposting & $\begin{array}{l}\text { "Big Red Worms" is a vermicomposting } \\
\text { operation that collects approximately } 10 \text { tons } \\
\text { of food waste per month from both on and } \\
\text { off campus eateries (De Grande, 2017). }\end{array}$ \\
\hline $\begin{array}{l}\text { University of New } \\
\text { Hampshire }\end{array}$ & Windrows & $\begin{array}{l}\text { All dining halls have installed food pulpers } \\
\text { to pulverize food waste into very small } \\
\text { pieces and to extract liquid, which increases } \\
\text { the speed the food waste decomposes and }\end{array}$ \\
\hline
\end{tabular}




\begin{tabular}{|l|l|l|}
\hline & & $\begin{array}{l}\text { eliminates the problem of odor. Interns are } \\
\text { hired to manage the collecting of food waste } \\
\text { and outreach (UNH, 2011). }\end{array}$ \\
\hline $\begin{array}{l}\text { North Carolina State } \\
\text { University }\end{array}$ & $\begin{array}{l}\text { Compost Learning Lab } \\
\text { and Vermicomposting }\end{array}$ & $\begin{array}{l}\text { The Lab has more than 20 different types of } \\
\text { backyard composting and vermicomposting } \\
\text { units ranging in capacity from 50 gallons to 2 } \\
\text { cubic yards. There is a 30-feet by 40-feet } \\
\text { "Worm Barn" with about a dozen } \\
\text { vermicomposting units (Davis, 2017). }\end{array}$ \\
\hline $\begin{array}{l}\text { North Dakota State } \\
\text { University }\end{array}$ & Windrows & $\begin{array}{l}\text { Turned by a front mount composter which } \\
\text { clean pens and } \\
\text { windrow the manure in the same pass } \\
\text { (Augustin \& Rahman, 2016). }\end{array}$ \\
\hline Ohio State University & Windrows & $\begin{array}{l}\text { Has an aeration system that includes: pipes, } \\
\text { holes, and fans. Windrow covers used as } \\
\text { temperatures decline (Reid, Keener \& } \\
\text { Wicks, 2010). }\end{array}$ \\
\hline $\begin{array}{l}\text { Washington State } \\
\text { University }\end{array}$ & In-vessel composter & $\begin{array}{l}\text { Existing campus facility that is in the } \\
\text { approval phase of starting research on } \\
\text { composting human remains (Nadauld, 2017). }\end{array}$ \\
\hline
\end{tabular}

This shows that a significant amount of LGUs have institutional composting in place and are making strides at expanding their programs campus-wide. Out of 69 LGUs nationwide, 18 have institutional composting programs, with majority of these at the larger schools. Some of these programs are newly developed and going through a trial run. Below is a table which summarizes the amount of LGU's that are using various types of institutional composting. 
Table 2: Popularity of Types of Institutional Composting at other LGUs

\begin{tabular}{|c|c|c|}
\hline Type of Composting & Number of LGUs & Percentage of LGUs* \\
\hline Windrows & 9 & $50 \%$ \\
\hline Vermicomposting & 5 & $28 \%$ \\
\hline In-vessel Composters & 5 & $28 \%$ \\
\hline Compost Stalls & 1 & $6 \%$ \\
\hline
\end{tabular}

*Note- Some LGUs utilize a combination of 2 methods (11\%).

This shows that windrows are the most common method used at LGUs, followed by vermicomposting and in-vessel composters. Compost stalls were the least commonly used method.

WVU is a part of the Big 12 Conference, which entails not just athletics but other university relations as well. There are three other LGUs within the Big 12 Conference. Of these LGUs, only one has implemented campus composting, Iowa State University (ISU). ISU uses windrows to compost, within a hoop barn to protect from the elements. The composting program is located on the school's dairy farm, with majority of waste coming from their operations, and the remainder coming from campus dining and campus yard waste. Approximately 50 percent of the solids from livestock manure is separated from the liquids and composted (Campus Ecology, 2010). The other half of the solid manure is mixed with water to also become liquid. This is because liquid manure is used as an alternative to fertilizer, it can be easily sprayed on the fields. Materials from ISU Dining, greenhouses, biomass research activities, and other university operations are brought to the facility and composted. This compost is then used to improve soil structure on the ISU campus farms. In 2009, more than 9000 tons of compost was created (Campus Ecology, 2010). This project was a major cost to the university but had support from 
stakeholders because of all the benefits it would bring to the school. It is a university-wide operation and took collaboration from many areas of the institution.

Considering other LGUs in the same region as WVU, the Ohio State University has a well-developed composting system and can be looked to as a model program. The Ohio State University utilizes a windrows system but with built-in aeration including pipes and fans. The university also has a uniquely designed pad that limits runoff by using berms. The Ohio State University has a well-established program that allows them to conduct research by manipulating composting factors, such as turning frequency, odors, rainfall simulation, and forced aeration (Reid, Keener \& Wicks, 2010). After looking to other LGUs, our own opportunities should now be investigated. 


\section{CASE STUDY}

At West Virginia University, the Davis College of Agriculture, Natural Resources and Design houses many of the areas of study that line up with LGU's original purpose, to teach agriculture, research agriculture, and outreach to the community. The mission of the Davis College is "to provide high-quality undergraduate and graduate education, conduct basic and applied research, engage in other creative and scholarly activities, and perform public outreach and service" (Mission and Vision, 2017).

The School of Agriculture and Food within the Davis College has two divisions: Animal and Nutritional Sciences, as well as Plant and Soil Sciences. These two divisions work closely together. WVU has thirteen farms and forests that are used for teaching, research, and outreach endeavors (Farms \& Forests, 2014). Two of the most active farms are right in the Morgantown area, the Animal Sciences Farm and the Organic Farm. The connected activity between these two farms, regarding composting, is the focus of this case study. 
Figure 1: Farms of Interest within the Greater Context of WVU and the Davis College

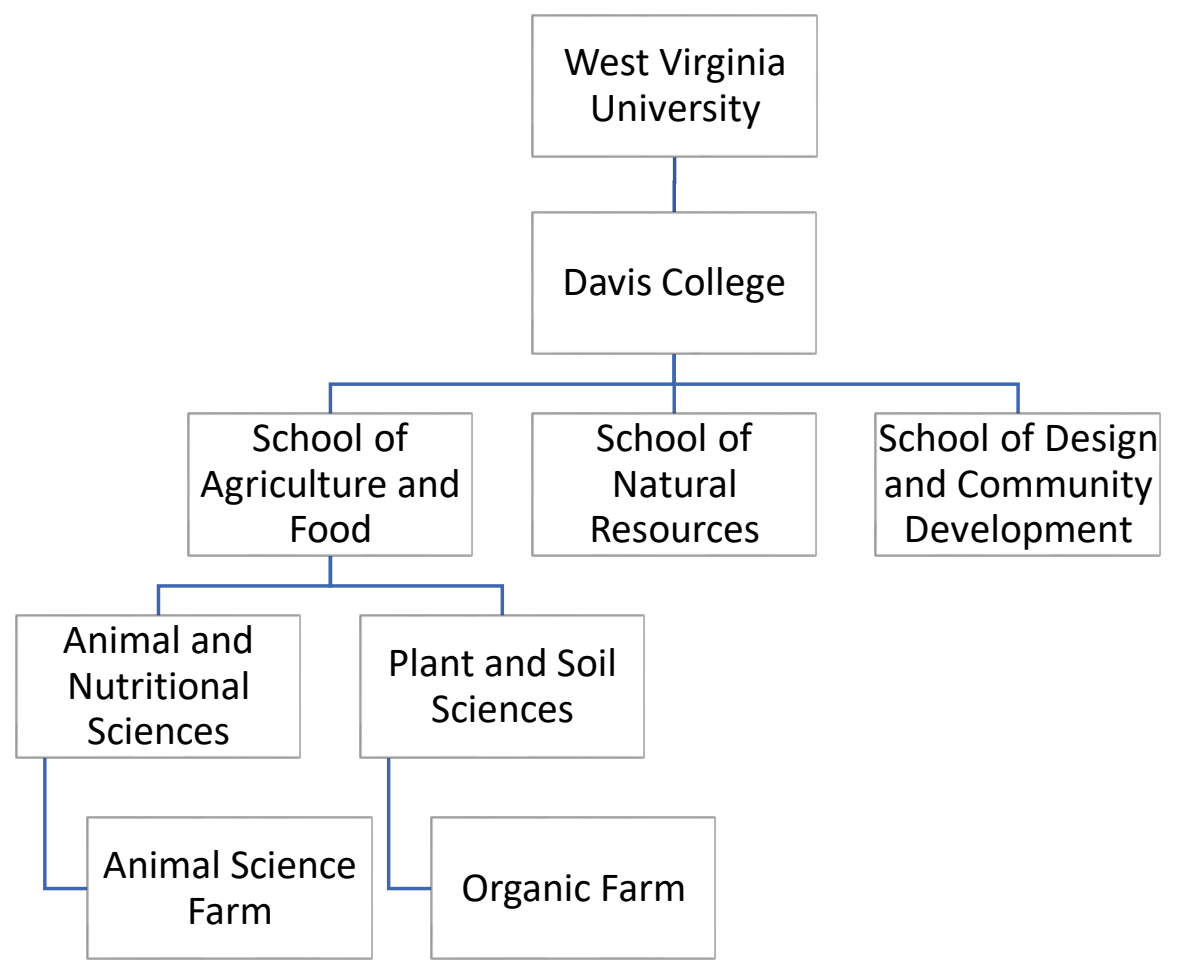


The Animal Sciences Farm is home to many of the activities of the Division of Animal and Nutritional Sciences. This farm encompasses 408 acres including the original 1895 dairy farm. During a typical year, the farm houses: 140 dairy animals, 60 beef cattle, 60 hogs, 170 sheep, 800 chickens, 50 turkeys and 100 ruffed grouse (Farms \& Forests, 2014). Some recent research topics include: muscle growth regulation, tissue complications in broiler-breeder chickens, and the environmental and economic impacts of nutrient flows in dairy forage systems. The Animal Sciences Farms serves as a living learning classroom for undergraduate and graduate students.

The waste management at the Animal Sciences Farm consists of piling animal manure for later use. Some of this manure is brought over to the Organic Farm on an as needed basis. The remaining manure from the pile can be converted to liquid manure to spray on the grounds of the Animal Sciences Farm, as well as other university farms outside the Morgantown area. The manure can be sold at market value, but it cannot be given away.

The Organic Farm is among the largest single certified organic research farms dedicated to teaching, research and outreach. It is also the first Certified Organic university farm in the United States. It houses many research projects within the Division of Plant and Soil Sciences. Research areas include pest management, pasture management, crop rotations, and organic sheep farming. Over $10 \mathrm{WVU}$ faculty are conducting ongoing research at the organic farm. 
Students can get involved in the mission of organic farming through classes, research, or volunteering. For example, the WVU People of Organic Practices is a student organization that provides high quality organic produce to our community by putting together community supported agriculture (CSA) baskets and helping with basic farm duties. The Organic Farm also features the Market Garden, a three-acre area that produces a variety of crops and serves as a research and marketing prototype. Within the Market Garden is a few small-scale composting stalls for disposing of crop waste and to serve as a teaching tool.

When animal manure is brought over from the Animal Sciences Farm, it is treated as raw waste when it reaches the Organic Farm to fertilize the soil. If the animal manure could be properly composted, it would be in a more viable form to be used on the Organic Farm. Below is a visual representation of the current activity between the farms. Organic rules dictate a mandatory time between application of manure and harvest, a time window not enforced when compost is applied. 
Figure 2: Current Composting Efforts and Compost Flow between the Farms

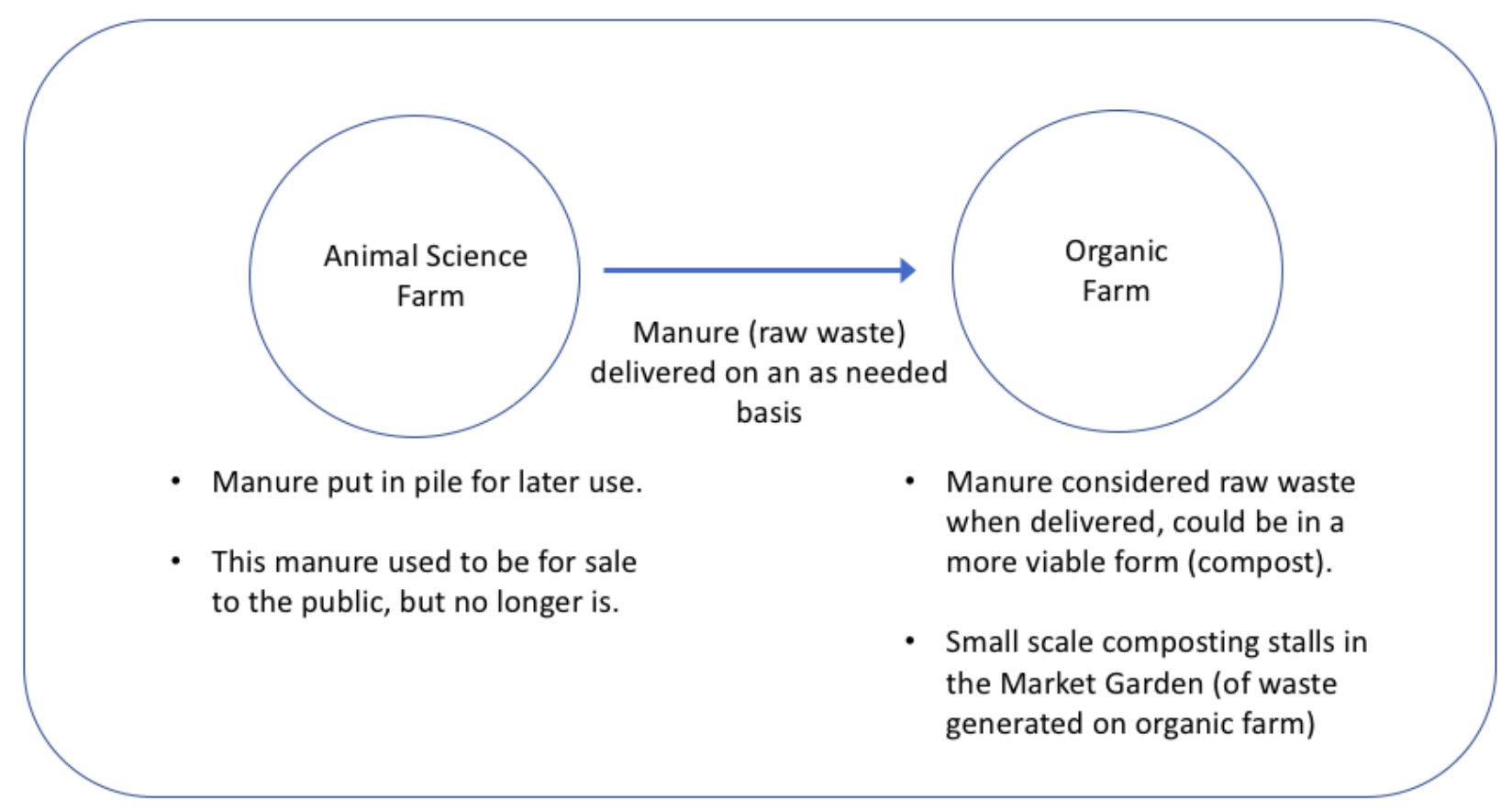

Figure 2 shows the current flow between the farms and its inefficiencies. If waste was properly managed at the Animal Science Farm it could be more useful to the Organic Farm and could be sold to the public without being a liability. A proper compost system could also provide the university with fertilizer to use across areas of campus. Nutrient rich compost would be invaluable to the Organic Farm, to help maintain soil health over time. A properly managed composting system would help turn waste into nutrient rich compost not just to the organic farm, but also for the university and the surrounding community. 
After speaking with Davis College professors and getting a better understanding of which composting method would work best for these farms, using windrows with proper turning machinery looks to be the best fit. The Animal Sciences Farm has ample space and would be the ideal site for institutional composting at WVU. This would also be fitting because majority of waste input going into the system is generated at the Animal Sciences Farm. This system would have the potential to accommodate the amount of animal waste that's currently being produced, as well as provide room for growth if the program expanded to included campus dining waste.

In order for this proposed system to run properly, the Animal Sciences Farm would need to hire a full-time staff member to manage and oversee the composting. This would ensure that the piles are at the right $\mathrm{C}: \mathrm{N}$ ratio before being advanced to composting, which is what is necessary for safe and viable compost. The more expensive startup cost of this proposed system would be the equipment. Turning machinery runs anywhere from $\$ 15,000$ to $\$ 60,000$. However, the startup cost of this type of composting is more affordable than other institutional composting systems, such as in-vessel composting, and would eventually pay for itself. 
The University of Wisconsin conducted a study that looked at the cost breakdown of windrow composting using various equipment per cow on a 60-cow farm. This study divided the total cost of each type of equipment (plus the cost of using it for a year) by the number of cows on the farm (60). The total investment costs per cow are $\$ 487 /$ cow for the compost turner, $\$ 256 /$ cow for the front-end loader, and \$210/cow for both the bulldozer and custom hire compost turner methods. The higher the number of cows on a farm, the better investment a compost turner would be. Although compost turner methods require the highest investment, they are also the most efficient way to make compost (CIAS, 1996). Other material costs of the project would be relatively low, possible including covers to insulate the windrows throughout the winter and current farm equipment to transport the manure to the windrows. Another cost would be developing a barrier around the windrows to prevent runoff to surrounding areas. This could be done by building a low wall or building a small berm.

Figure 3: Proposed Composting Efforts and Compost Flow between the Farms (Phase I)

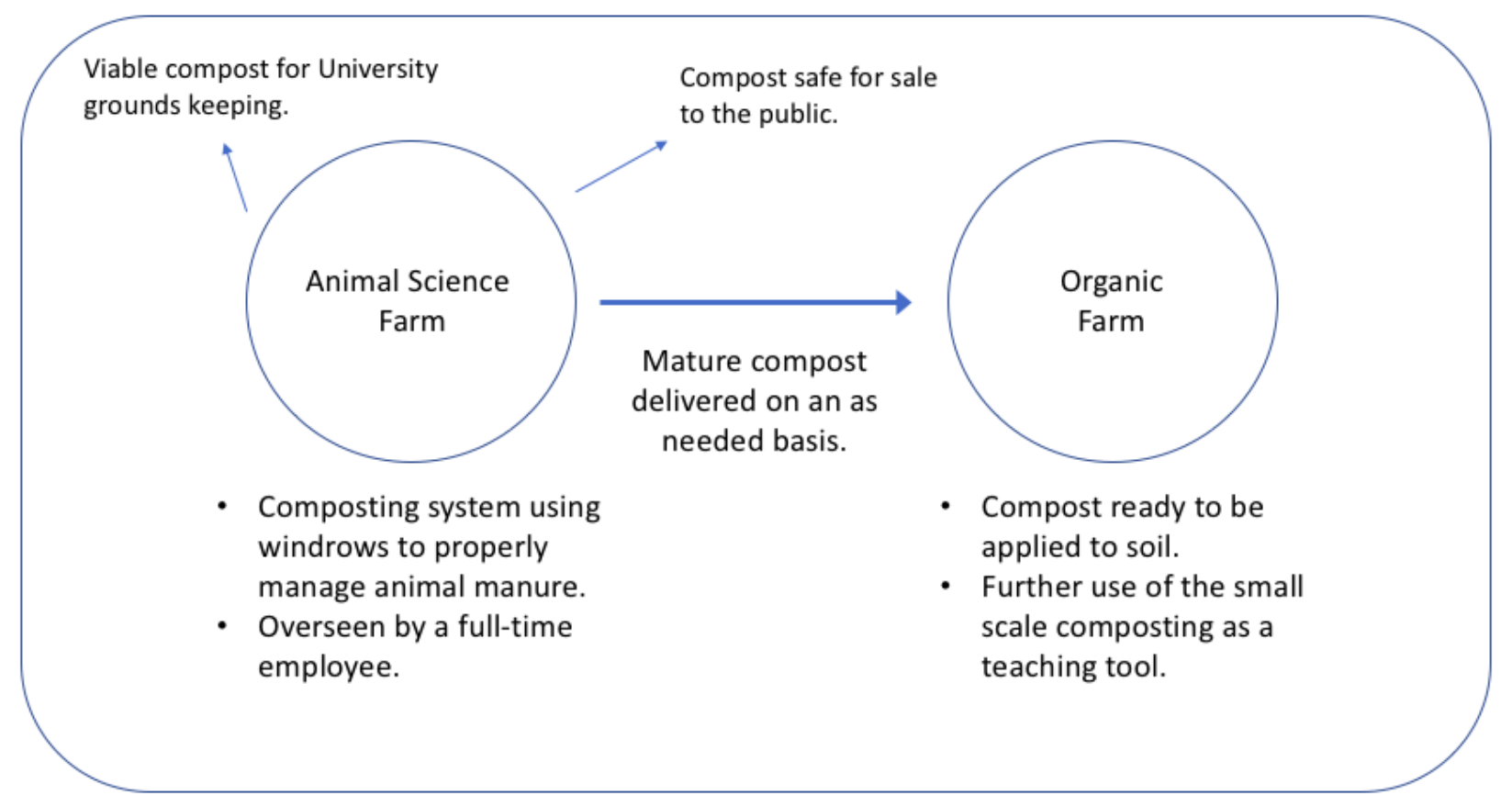


Some limiting factors in this case study included limited access to management at the Animal Sciences Farm. After multiple contact attempts assessment was gathered from other sources within the Davis College. Another limiting factor would be the lack of interest from university administration and stakeholders however this investigation should help shed light onto the issue and can be used as a starting point of discussions. The start-up of this project would require a significant amount of funding; however, it would generate a significant return on investment over time. 


\section{DISCUSSION}

Our food system is a complex flow of energy and foods, it is not linear or circular (Chase \& Grubinger, 2014). They are webs of people and the resources and behaviors they affect. The food system has been defined as "an interconnected web of activities, resources and people that extends across all domains involved in providing human nourishment and sustaining health, including production, processing, packaging, distribution, marketing, consumption and disposal of food". The main input and output factors being investigated here are how wastes can be transformed back into natural resources through composting. Farms can help support the local food system by improving their composting systems to be able to integrate food waste as well.

With a growing world population and decreasing resources, developing sustainable food systems has been at the forefront of recent policy development and program missions (Tagtow et al., 2014). Issues of sustainability apply to all aspects of nutrition and dietetics practice and can be practiced at both the program and systems level (Tagtow et al., 2014). As client and public educators, Registered Dietitians are uniquely positioned to meet the growing needs of those seeking guidance on food choices as they relate to ecological responsibility (Robinson \& Gerald, 2016). The term food citizenship is described as the practice of engaging in behaviors that support, rather than threaten, the development of a just and environmentally sustainable food system (Wilkins, 2005). We must be responsible food citizens by looking after our local food system as well our university’s food system. 
One method of food system support is food recovery. Food recovery involves methods aimed at diverting food from landfills. These alternatives include: source reduction, feeding the hungry, feeding animals, industrial uses, and composting. Sending food to the landfill or for incineration should be a last resort of disposal (Robinson \& Gerald, 2016). WVU has the opportunity to divert a significant amount of waste from going to landfills by beginning a properly managed compost system.

WVU could also utilize this new system to serve as a living learning classroom for students and the community. By seeing how composting works firsthand through classes or workshops, students would have a lasting impression of the importance of compost which could help gain support for the program and encourage better waste management. The composting system could also be an outreach tool for the community to learn and be engaged in the local food system.

Even the most sustainably grown food does no good if the food is never eaten. A sizeable portion of our nation's land and budget is put towards growing food, yet $40 \%$ of food in the United States today goes uneaten (Gunders, 2012). This not only means we are wasting the equivalent of $\$ 145$ billion annually, but also that all that uneaten food ends up in landfills and is the biggest component of U.S. municipal solid waste (Gunders, 2012). That high of a wasted proportion of food is shameful. One in six Americans lack a secure supply of food and reducing this food waste would help to solve that problem as well as help the environment and reduce methane production in landfills (Gunders, 2012).

Reducing our food waste involves collaborative efforts between businesses, governments and consumers. The government's role would be to conduct studies on our current food losses and set national goals to reduce food waste. Businesses can play a part in streamlining their 
operations. While consumers, may play the biggest part in that they can avoid buying excess food, use what they buy, and eat their leftovers. The average American consumer today wastes ten times as much food as someone in Southeast Asia and 50\% more than Americans did back in the 1970s (Gunders, 2012). This means that there was a time when we had significantly less waste and that we can get back to that point again with a collaborative effort. There are many routes that food waste can take for disposal, the last resort should be the landfill.

WVU dining services have been making recent strides towards becoming a more sustainable part of the food system, this has mostly involved increasing recycling and using trayless dining. However, there is much more room for improvement when it comes to reducing food waste on campus. The Food Recovery Network is now an active organization on campus aimed repurposing food waste from the dining halls. In September 2011 Food Recovery Network (FRN) was created as a student group at the University of Maryland when a few students realized how much good food was being thrown away at the dining halls (Food Recovery Network, 2017). Today FRN is the largest student movement against food waste and overall, they have saved more than 1.2 million meals that were later donated to those in need (Food Recovery Network, 2017).

One study that compared universities with zero waste campaigns, showed there is a direct correlation between amount of monetary and personnel investment in waste management programs and achievement in waste diversion (Ebrahimi \& North, 2017). In order for us to make progress in decreasing our waste as a university, we must invest in programming to spark this change.

As the potential new composting program expands, it could grow to include dining hall waste and landscaping scraps, like other LGU's have managed to do. Achieving this would need 
to include having a clear system at the tray return in the dining halls to show students both what counts as compost and where to put it. Collecting and screening the compost waste from the dining halls could be achieved by the proposed compost manager position, dining hall staff, and potentially student volunteers. Expanding this program to the dining halls would mean a significant amount of food waste could be diverted from landfills and re-introduced into our WVU food system. This would also allow students outside of the Davis College to learn about the importance of composting and the impact it can have. See below the proposed flow of waste and compost at WVU if food waste was added to the system.

Figure 4: Proposed Composting Efforts and Compost Flow between the Farms and University (Phase II)

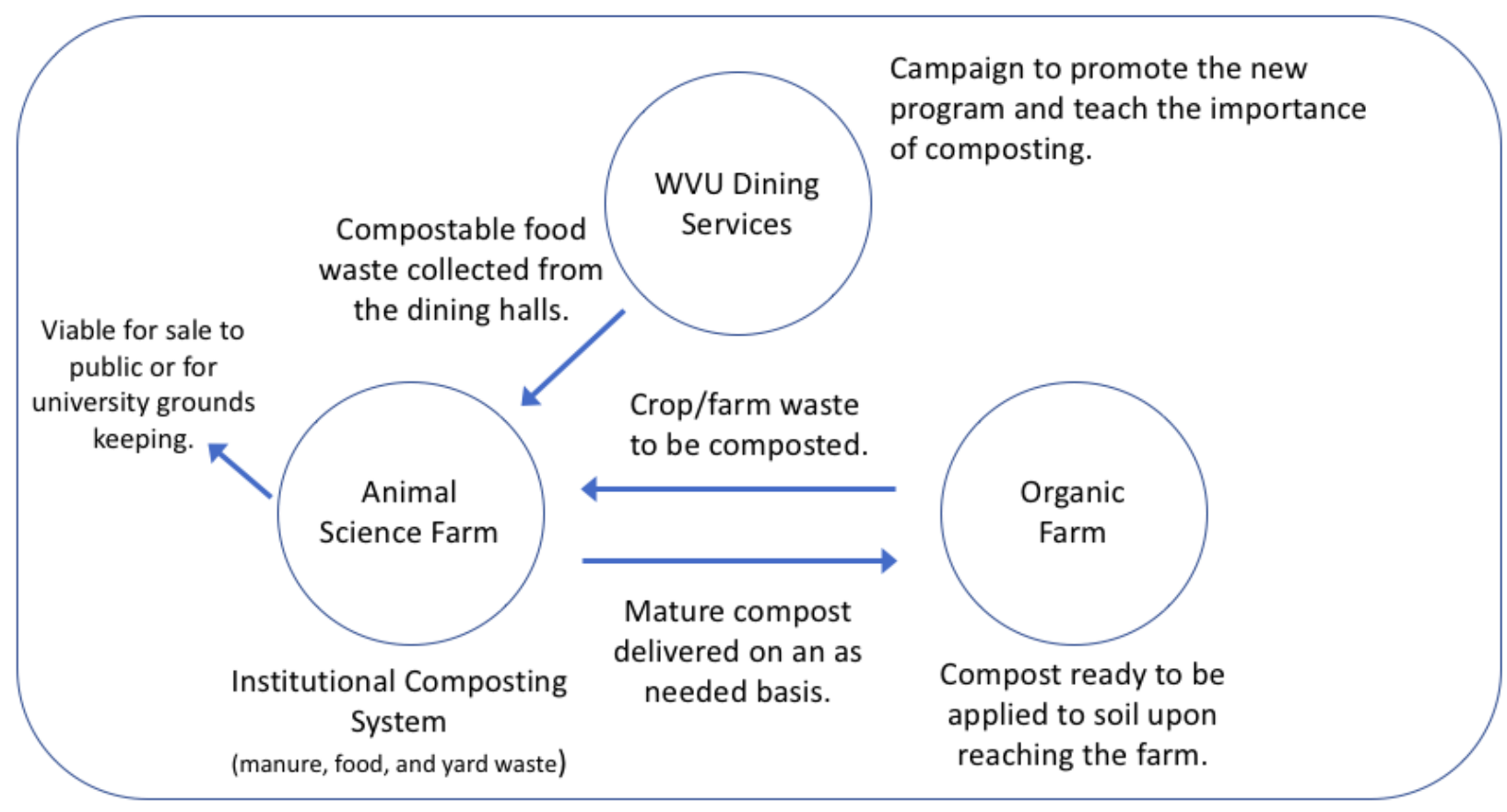

The feasibility of this co-composting concept was investigated at the University of New Hampshire (UNH). UNH was already composting manure and yard waste but received a grant to study introducing food waste into the system (Adams, 1993). A moderate cost, open air windrow technology was used, mainly employing existing farm equipment. The results of the pilot 
demonstrated that composting projects on farms can handle a number of wastes, such as food and soiled paper napkins, and produce a useable and potentially saleable product (Adams, 1993). With many LGU's places an emphasis on more sustainable and green dining services, it's important that we follow suit and continue to find innovative ways to improve. 


\section{CONCLUSION}

Composting provides a superior, environmentally friendly and simple alternative to organic waste disposal (Crohn, 2011). West Virginia University, as a land grant university, has the opportunity to use its research farms to close a gap in our local food system by developing proper institutional composting that will allow us to reuse farm waste and food waste in a safe and effective manner. Other land grant universities have started similar programs and also have been successful in expanding the programs university wide.

Although starting this program would be a significant investment, it would have environmental, economic, and social benefits. The initial investment would have eventual payoff if the system were to be expanded campus wide and utilized for its full potential. It would also serve as a platform for teaching, research, and outreach to apply the land grant mission in a new way at West Virginia University. 


\section{REFERENCES}

Adams, N. E. (1993). Composting food waste on the farm. BioCycle; Emmaus, 34(6), 73.

Adler, S., Blaha, K., Lipman, R., Saunders, K., \& Wang, J. (2009). Implementation of a Composting Program at the University of Delaware: Sustainability Report. Retrieved from http://udel.edu/ rlipman/lipman_eportfolio/showcase/compostingatUD.pdf

Association of Public and Land-Grant Universities (APLU). (2012). The Land-Grant Tradition. Retrieved from http://www.aplu.org/library/the-land-grant-tradition/file

Augustin, C., \& Rahman, S. (2016, July). Composting Animal Manures: A guide to the process and management of animal manure compost. NDSU Extension Service. Retrieved from https://www.ag.ndsu.edu/publications/livestock/composting-animal-manures-a-guide-tothe-process-and-management-of-animal-manure-compost/nm1478.pdf

CalRecycle. (2013, September 11). Case Studies on Compost Use in Agriculture. Retrieved March 10, 2018, from

http://www.calrecycle.ca.gov/organics/Farming/CaseStudies/default.htm\#Earthbound Campus Ecology. (2010). Iowa State University Waste Reduction. National Wildlife Federation. Retrieved from https://kids.nwf.org/ /media/Campus-Ecology/Files/Case-Studies/IowaState-University-2010-Case-Study-Waste-Reduction-FINAL.ashx

Center for Integrated Agricultural Systems (CIAS). (1996, June). Windrow composting systems can be feasible, cost effective (Research Brief \#20) | Center for Integrated Agricultural Systems. Retrieved March 19, 2018, from https://www.cias.wisc.edu/windrow-compostingsystems-can-be-feasable-cost-effective/

Chase, L., \& Grubinger, V. (2014). Food, Farms and Community: Exploring Food Systems. Retrieved from http://www.uvm.edu/vtvegandberry/Intro_Food_Systems.pdf

Chen, J. H., \& Wu, J. T. (2005). Benefits and drawbacks of composting. Compost Production: A manual for Asian farmers. Food \& Fertilizer Technology Center. Taipei, 106.

Compost Research Site at the Horticulture Farm. (2012). Retrieved January 7, 2018, from http://recycle.msu.edu/index.php/services/composting-digestion/

Composting at UConn. (2017). Retrieved January 7, 2018, from https://ecohusky.uconn.edu/composting-at-uconn/ 
Composting Problems (Troubleshooting). (2010). Retrieved March 14, 2018, from https://www.planetnatural.com/composting-101/making/problems/

Crohn, D. M. (2011, March). Impact of Compost Application On Soil Erosion and Water Quality. CalRecycle. Retrieved from http://www.calrecycle.ca.gov/Publications/Documents/1377/2011013.pdf

Davis, C. (2017, June 29). At This Campus Lab, Worms Eat Your Leftovers. Retrieved January 7, 2018, from https://composting.ces.ncsu.edu/2017/06/at-this-campus-lab-worms-eat-yourleftovers/

De Grande, Z. (2017, February 17). UNL composting initiative flourishes, expands on campus. Retrieved January 7, 2018, from https://sustainability.unl.edu/unl-composting-initiativeflourishes-expands-campus

Farms \& Forests. (2014). Retrieved from http://davis.wvu.edu/research/farms-forests

Food Recovery Network. (2017). Retrieved February 22, 2018, from https://www.foodrecoverynetwork.org/aboutus/

Grant, Z. (2015, March 10). Vermicompost (In Progress). Retrieved January 7, 2018, from https://icap.sustainability.illinois.edu/project/vermicompost

Guiden, M. (2017, April 17). Campus composting efforts expanding. Retrieved January 7, 2018, from https://source.colostate.edu/campus-composting-efforts-expanding/

Gunders, D. (2012). Wasted: How America Is Losing Up to 40 Percent of Its Food from Farm to Fork to Landfill. NRDC Issue Paper. Retrieved from https://www.nrdc.org/sites/default/files/wasted-food-IP.pdf

Kashmanian, R. M., \& Rynk, R. F. (1998). Creating positive incentives for farm composting. American Journal of Alternative Agriculture, 13(1), 40-45. https://doi.org/10.1017/S0889189300007608

Kianoosh Ebrahimi, \& Leslie A. North. (2017). Effective strategies for enhancing waste management at university campuses. International Journal of Sustainability in Higher Education, 18(7), 1123-1141. https://doi.org/10.1108/IJSHE-01-2016-0017

Martin, S. (2017, March 8). Student-run Campus Composting program aims to reduce waste on campus. Retrieved January 7, 2018, from http://www.uga.edu/about_uga/profile/zerowaste-uga/ 
Mason, S. (2016). Improperly Constructed Compost Piles Attract Pests. Retrieved March 14, 2018, from http://web.extension.illinois.edu/cfiv/homeowners/990522.html

Mission and Vision. (2017, August 19). Retrieved March 6, 2018, from https://www.davis.wvu.edu/about-davis-college/mission-and-vision

Nadauld, T. (2017, September 23). Washington State University eyes composting human remains. Retrieved January 7, 2018, from http://www.spokesman.com/stories/2017/sep/23/washington-state-university-eyescomposting-human-/

National Institute of Food and Agriculture. (2014). Retrieved February 28, 2017, from https://nifa.usda.gov/resource/land-grant-colleges-and-universities-map

Platt, B., N. Goldstein, C. Coker \& S. Brown. (2014). State of Composting in the US: What, Why, Where \& How? Institute for Local Self-Reliance, 2014.

Reid, G., Keener, H., \& Wicks, M. (2010). The Evolution of Composting at Ohio State University: The Practical Aspects of Compost Management. Ohio Agricultural Research and Development Center. Retrieved from https://ocamm.osu.edu/sites/ocamm/files/imce/Compost/Compost_Presentations/Reid_OAR DC_compost.pdf

Robinson-O'Brien, R., \& Gerald, B. L. (2016). Practice Paper of the Academy of Nutrition and Dietetics: Promoting Ecological Sustainability within the Food System. Academy of Nutrition and Dietetics. Retrieved from http://www.eatrightpro.org/ /media/eatrightpro\%20files/practice/position\%20and\%20practi ce\%20papers/practice\%20papers/practice\%20papers/sustainability_march_13.ashx

Tagtow, A., Robien, K., Bergquist, E., Bruening, M., Dierks, L., Hartman, B. E., ... Wilkins, J. (2014). Academy of Nutrition and Dietetics: Standards of Professional Performance for Registered Dietitian Nutritionists (Competent, Proficient, and Expert) in Sustainable, Resilient, and Healthy Food and Water Systems. Journal of the Academy of Nutrition and Dietetics, 114(3), 475-488.e24. https://doi.org/10.1016/j.jand.2013.11.011

Teague, Zoe (2011) "Implementing a Food Waste to Compost Program at the University of Arkansas: An Economic Feasibility Analysis," Inquiry: The University of Arkansas 
Undergraduate Research Journal: Vol. 12, Article 5. Available at:

http://scholarworks.uark.edu/inquiry/vol12/iss1/5

Themelis, N. J., \& Arsova, L. (2015, February 13). Calculating Tons To Composting In The U.S. BioCycle, 56(2), 27.

UA Compost Cats. (2017). Retrieved January 6, 2018, from http://www.compostcats.com

UMaine Opens New Campus Composting Facility. (2013, January 14). Retrieved January 7, 2018, from https://umaine.edu/news/blog/2013/01/14/plate-to-plant/

UNH's Compost Program. (2011, May 19). Retrieved January 7, 2018, from https://sustainableunh.unh.edu/compost

University of Illinois Extension. (2017). Composting in the Home Garden - Common Questions. Retrieved March 14, 2018, from https://extension.illinois.edu/compost/process.cfm

US EPA. (2015, August 19). Types of Composting and Understanding the Process [Overviews and Factsheets]. Retrieved March 15, 2018, from https://www.epa.gov/sustainablemanagement-food/types-composting-and-understanding-process

Wilkie, A. (2017, April 24). Student Compost Cooperative [Blog]. Retrieved January 7, 2018, from http://biogas.ifas.ufl.edu/SCC/

Wilkins, J. L. (2005). Eating Right Here: Moving from Consumer to Food Citizen. Agriculture and Human Values, 22(3), 269-273. https://doi.org/10.1007/s10460-005-6042-4

Zahren, B. (2017, June 1). Compost facility is the answer to varied campus needs. Retrieved January 7, 2018, from https://www.inside.iastate.edu/article/2017/06/01/compost

Zhang, Y. (2011, October 19). Composting facility at Bradford Research Farm soon to be finished [Newspaper]. Retrieved January 7, 2018, from https://www.columbiamissourian.com/news/composting-facility-at-bradford-research-farmsoon-to-be-finished/article_31069792-723e-52c9-999c-e38b5f64a8d2.html 


\section{LIST OF FIGURES}

Figure 1: Farms of Interest within the Greater Context of WVU and the Davis College..........19

Figure 2: Current Composting Efforts and Compost Flow between the Farms.................22

Figure 3: Proposed Composting Efforts and Compost Flow between the Farms (Phase I).......24

Figure 4: Proposed Composting Efforts and Compost Flow between the Farms and University

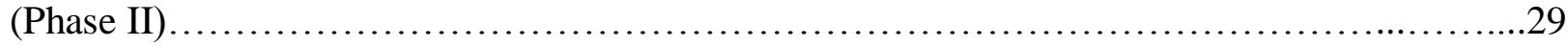




\section{LIST OF TABLES}

Table 1: Summary of Data Collected on Composting Methods at Other LGUs ....................... 13

Table 2: Popularity of Types of Institutional Composting at other LGUs ................................. 16 


\section{APPENDIX}

\section{Land Grant Institutions by State}

Alabama: Alabama A\&M University, Auburn University, Tuskegee University

Alaska: University of Alaska

Arizona: University of Arizona (Tucson)

Arkansas: University of Arkansas, University of Arkansas at Pine Bluff

California: University of California System (Oakland as headquarters)

Colorado: Colorado State University

Connecticut: University of Connecticut

Delaware: Delaware State University, University of Delaware

DC: University of the District of Columbia

Florida: Florida A\&M University, University of Florida

Georgia: Fort Valley State University, University of Georgia

Hawaii: University of Hawaii (Honolulu)

Idaho: University of Idaho

Illinois: University of Illinois (Urbana-Champaign)

Indiana: Purdue University

Iowa: Iowa State University

Kansas: Kansas State University

Kentucky: Kentucky State University, University of Kentucky

Louisiana: Louisiana State University, Southern University and A\&M College

Maine: University of Maine

Maryland: University of Maryland, University of Maryland Eastern Shore

Massachusetts: University of Massachusetts

Michigan: Michigan State University

Minnesota: University of Minnesota

Mississippi: Alcorn State University, Mississippi State University

Missouri: Lincoln University, University of Missouri

Montana: Montana State University

Nebraska: University of Nebraska 
Nevada: University of Nevada

New Hampshire: University of New Hampshire

New Jersey: Rutgers University (New Brunswick)

New Mexico: New Mexico State University

New York: Cornell University

North Carolina: North Carolina A\&T State University, North Carolina State University

North Dakota: North Dakota State University

Ohio: Central State University, Ohio State University

Oklahoma: Langston University, Oklahoma State University

Oregon: Oregon State University

Pennsylvania: Pennsylvania State University

Rhode Island: University of Rhode Island

South Carolina: Clemson University, South Carolina State University

South Dakota: South Dakota State University

Tennessee: Tennessee State University (Nashville), University of Tennessee (Knoxville)

Texas: Prairie View A\&M University, Texas A\&M University (College Station)

Utah: Utah State University

Vermont: University of Vermont

Virginia: Virginia Tech (Blacksburg), Virginia State University

Washington: Washington State University

West Virginia: West Virginia State University, West Virginia University

Wisconsin: University of Wisconsin

Wyoming: University of Wyoming

(National Institute of Food and Agriculture, 2014) 